\title{
50. ORGANIC-CARBON CONTENT OF SEDIMENTS AND ROCKS FROM DEEP SEA DRILLING PROJECT SITES 603, 604, AND 605, WESTERN MARGIN OF THE NORTH ATLANTIC ${ }^{1}$
}

\author{
Philip A. Meyers, The University of Michigan²
}

\begin{abstract}
The organic matter contents of sediments and rocks sampled during DSDP Leg 93 have been characterized by CHN and Rock-Eval analyses. Most samples from Sites 604 and 605 on the New Jersey continental slope and from Site 603 on the Hatteras outer continental rise contained less than $0.5 \%$ organic carbon. Some Neogene samples from the slope contained 1 to $2 \%$ organic carbon, and Cretaceous samples from the outer rise were as rich as $13.6 \%$ organic carbon by weight. Thin layers of black claystones of Santonian, Cenomanian, and Albian age were found interbedded in organiccarbon-lean, bioturbated, turbiditic claystones. Similar layers of turbiditic black marlstones were interspersed among Neocomian limestones and sandstones. Although the organic matter in many of the samples appeared to be detrital continental material, according to Rock-Eval and $\mathrm{C} / \mathrm{N}$ values, Cenomanian black shales, in particular, contained substantial proportions of marine-derived organic matter.
\end{abstract}

\section{INTRODUCTION}

Incorporation of organic matter into deep-sea sediments is sensitive to a number of factors. Production by marine biota, transport from continental sources, period of sinking through an oxygenated water column, and rate of burial in the sea bottom are some of the major determinants. A fundamental parameter in organic geochemical investigations of sediments is the organic-carbon content, which is directly linked to the amount of organic matter present. This parameter is in turn a reflection of the depositional environment and the interaction of those physical, chemical, and biological factors influencing organic matter in sediments.

Other useful bulk organic geochemical parameters include the $\mathrm{C} / \mathrm{N}$ atomic ratio and Rock-Eval pyrolysis, both of which provide insights into the type of organic matter contained within sedimentary deposits. $\mathrm{C} / \mathrm{N}$ values of 14 and higher have been used as identifiers of terrigenous organic matter, whereas those between 4 and 8 often typify marine material (Müller, 1977; Premuzic et al., 1982). These values can be altered, however, by diagenesis (Waples and Sloan, 1980) and hence must be used cautiously. The Rock-Eval procedure, described by Espitalié et al. (1977), determines the hydrocarbon-generating potential and thermal maturity of organic matter in rocks and can provide evidence of the source of bulk organic matter.

During DSDP Leg 93 in the northwestern Atlantic Ocean, samples of sediment and rock from Sites 603, 604 , and 605 (Fig. 1) were routinely collected for organic matter analysis. The results of organic carbon, $\mathrm{C} / \mathrm{N}$ atomic ratio, and Rock-Eval determinations of these samples are summarized here and discussed in the context of their sedimentary environment.

\footnotetext{
1 Van Hinte, J. E., Wise, S. W., Jr., et al., Init. Repts. DSDP, 93: Washington (U.S. Govt, Printing Office).

2 Address: Oceanography Program, Department of Atmospheric and Oceanic Science, The University of Michigan, Ann Arbor, MI 48109-2143.
}

\section{ANALYSIS}

\section{Organic-Carbon Determinations}

Organic-carbon analyses were done using a Hewlett-Packard 185-B $\mathrm{CHN}$ Analyzer. Portions of samples selected for calcium carbonate determinations were treated with dilute $\mathrm{HCl}$ to remove carbonate, washed with deionized water, and dried at $110^{\circ} \mathrm{C}$. A Cahn Electrobalance was used to weigh 20 -mg samples of sediment for $\mathrm{CHN}$ analysis. Samples were combusted at $1050^{\circ} \mathrm{C}$ in the presence of an oxidant, and the volumes of the evolved gases determined as measures of the $\mathrm{C}, \mathrm{H}$, and $\mathrm{N}$ contents of sediment organic matter. Areas of gas peaks were determined and compared to those of rock standards of known carbon and nitrogen contents (Meyers, Brassell, et al., 1984). These values were used to standardize instrument response so that $\mathrm{C} / \mathrm{N}$ atomic ratios could be reported. Organic-carbon concentrations were calculated on the basis of initial sediment dry weight. Hydrogen elemental analysis with the procedure used is untrustworthy because of variable amounts of clay minerals and their hydrates, hence hydrogen values are not reported for samples analyzed by this method.

\section{Calcium Carbonate Determinations}

Concentrations of carbonate minerals were determined by the "Karbonate Bombe" procedure of Müller and Gastner (1971) as improved by Dunn (1980). Dried samples of sediment and rock were ground, and about $1 \mathrm{~g}$ was treated with concentrated $\mathrm{HC} 1$ in a closed cylinder. The resulting increase in pressure because of the formation of $\mathrm{CO}_{2}$ gas is proportional to the concentration of carbonate. All carbonate minerals are assumed to exist as calcium carbonate in this chapter.

\section{Rock-Eval Procedure}

The source character and maturity of organic matter in selected rock samples were determined with the shipboard Girdel Rock-Eval pyrolysis instrument, which uses the I.F.P.-FINA process described by Espitalié et al. (1977). About $100 \mathrm{mg}$ of coarsely ground, dry sample is heated from 250 to $550^{\circ} \mathrm{C}$ at a rate of $25 \mathrm{C} / \mathrm{min}$. Gases released during this heating are carried off in a helium stream, which is split into two parts. One part is directed through a flame ionization detector to monitor hydrocarbons; the other passes through a $\mathrm{CO}_{2}$ trap to be released at the end of the heating program and to be measured by a thermal conductivity detector.

This pyrolysis procedure yields four parameters that characterize the organic matter in a sample: (1) Area of peak $S_{1}$, which corresponds to the quantity of free hydrocarbons present in the sample. (2) Area of peak $\mathrm{S}_{2}$, which corresponds to the quantity of hydrocarbons released by pyrolysis of kerogen up to $550^{\circ} \mathrm{C}$, or the "hydrocarbon potential." (3) Temperature, $T_{\max }$, of the top of peak $S_{2}$, which is related to the maturity of the organic matter. (4) Area of peak $S_{3}$, which corresponds to the $\mathrm{CO}_{2}$ released from pyrolysis of kerogen. From $\mathrm{S}_{1}$ and $\mathrm{S}_{2}$, the "hydrocarbon production index," or ratio of $\mathrm{S}_{1} /\left(\mathrm{S}_{1}+\mathrm{S}_{2}\right)$, may 


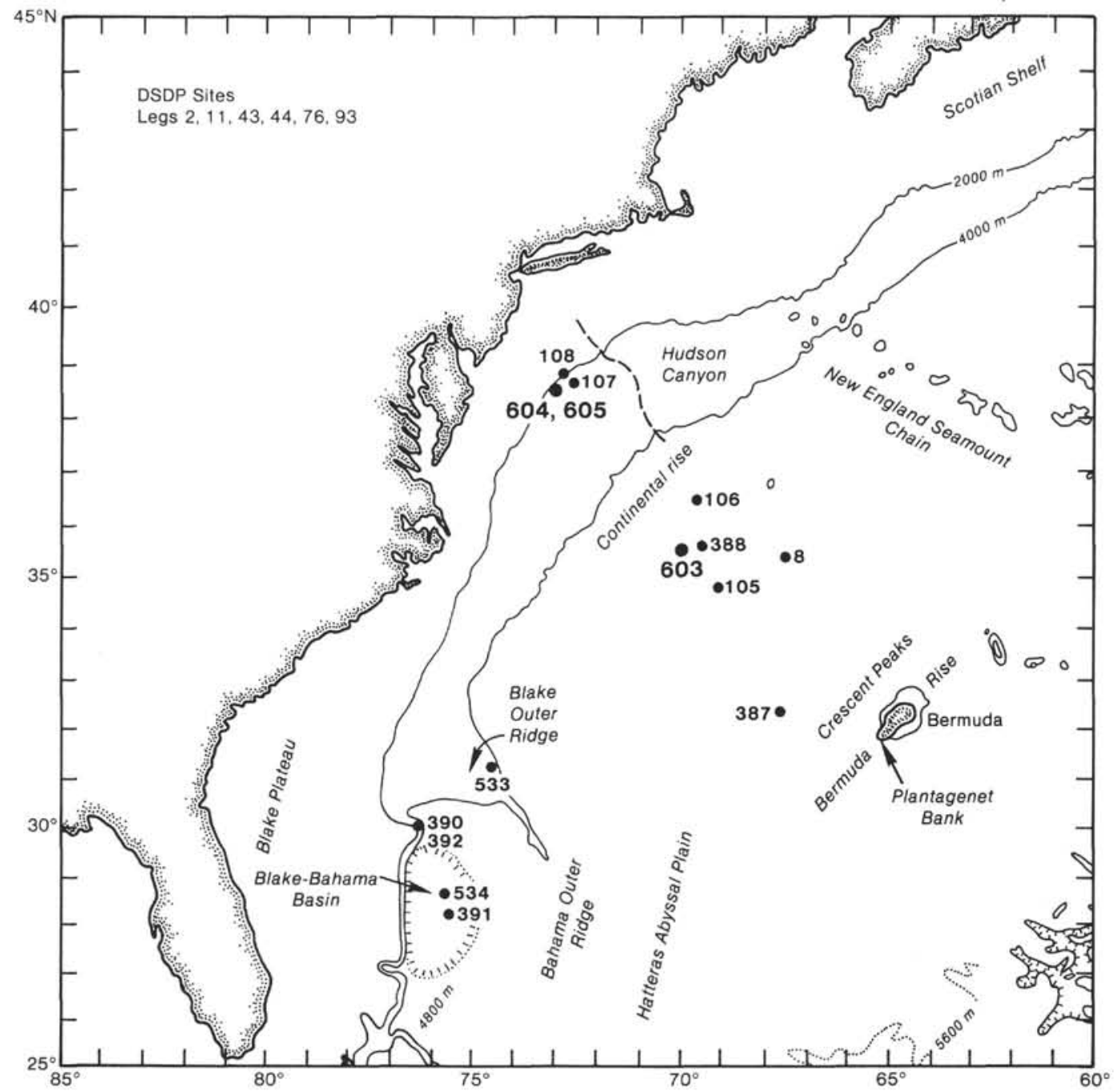

Figure 1. Locations of Sites 603, 604, and 605 and of earlier DSDP sites in the western North Atlantic Ocean.

be calculated. From $\mathrm{S}_{2}, \mathrm{~S}_{3}$, and the organic-carbon concentration, the hydrogen index $(\mathrm{HI})$ and oxygen index $(\mathrm{OI})$ can be calculated and used to determine kerogen source character and maturity.

\section{RESULTS AND DISCUSSION}

\section{Site 603-Outer Hatteras Rise}

Site 603 is located in $4334 \mathrm{~m}$ of water on the lower continental rise off North Carolina (Fig. 1). Leg 93 rotary drilled and cored Holes 603 and 603B and used the variable-length hydraulic piston corer (HPC) and extended core barrel (XCB) to recover the uppermost $366 \mathrm{~m}$ of the section in Hole 603C. A nearly continuous record of sediment accumulation from Pleistocene to Berriasian times was recovered from these three holes. The lithologic units encountered at Site 603 are shown in Figure 2 and are described in the Site 603 chapter (this volume).

Organic-carbon concentrations and organic-matter atomic $\mathrm{C} / \mathrm{N}$ values from groups of Site 603 samples are summarized in Table 1, along with descriptions of the lithologic subunits they represent. Data from individual samples are listed in Meyers (this volume). In general, samples from Units IV and V are richer in organic car- bon than are samples from Units I, II, and III, although considerable variability is especially evident in Unit IV (Table 1).

The amount of organic carbon present in deep-sea sediments is a fraction of the material originally available from marine production and continental runoff. Microbial and oxidative processes degrade sinking organic matter, and further losses are large during the early stages of burial in the seafloor. The importance of the latter phase of degradation is diminished by rapid burial in areas of high sedimentation rates, with the result that concentrations of organic carbon are enhanced, but still higher rates of sediment accumulation act to dilute, as well as to preserve, organic matter in the sea bottom (Müller and Suess, 1979; Ibach, 1982).

The relatively low concentrations of organic carbon present in samples from Subunits IA, IB, and IC reflect deposition beneath waters lacking high productivity and in an environment having a high rate of sediment accumulation. Preservation of the modest supply of organic matter appears to have been enhanced, yet concentrations have been diluted by the high sedimentation rates found in these Neogene contourite deposits. 


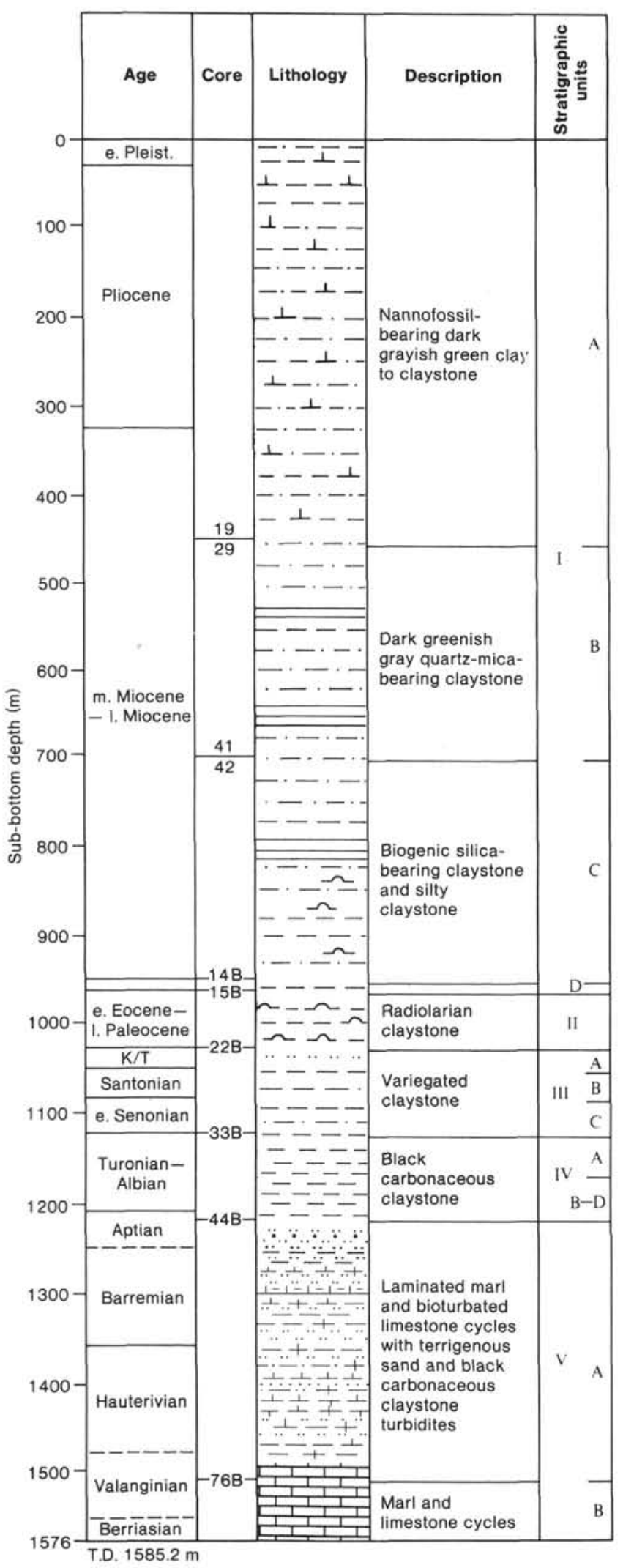

Figure 2. Stratigraphic summary of Site 603 on the Outer Hatteras Rise. B following the core number indicates cores from Hole 603B.
Both organic carbon concentrations and $\mathrm{C} / \mathrm{N}$ values decrease slightly over the upper $698 \mathrm{~m}$ of Site 603 . Waples and Sloan (1980) report decreases in concentrations of organic carbon and in $\mathrm{C} / \mathrm{N}$ ratios with depth in Neogene sediments from DSDP Leg 58 in the western North Pacific. They attribute these downhole decreases to continued microbial degradation of organic matter with preferential losses occurring to carbon, rather than to nitrogen. Such microbial activity would result in the evolution of microbial gases, which were indeed abundant in Hole 603 and $603 \mathrm{C}$ cores (Site 603 chapter, this volume).

In Subunit IC, concentrations of organic carbon and atomic $\mathrm{C} / \mathrm{N}$ ratios are similar to those present in Subunit IA and are substatially higher than those from Subunit IB. These higher values are contrary to what would be expected from continued diagenetic alteration of material deposited under uniform conditions, and hence they signal some sort of change in the paleoceanographic setting. Because biogenic silica also increases in Subunit IC, it is possible that biological productivity was greater during this period of sediment deposition than at later times and is recorded in the silica, organic carbon, and $\mathrm{C} / \mathrm{N}$ values.

In samples below Subunit IC, the extremely low organic-carbon values indicate little input of organic matter from either marine or continental sources and deposition under oxygenated conditions, giving poor preservation of organic matter. $\mathrm{C} / \mathrm{N}$ ratios change from values of around 9 in samples from Subunit IC to values of 6 or less in Subunit ID, Unit II, and Subunit IIIA. The abrupt decrease in $\mathrm{C} / \mathrm{N}$ ratios at $950 \mathrm{~m}$ sub-bottom indicates a paleoceanographic change, probably in productivity.

Dark-colored claystones ("black shales") are first encountered in Subunit IIIB and continue to occur throughout deeper parts of Site 603 . The black-colored claystones are rich in organic matter, ranging up to $13.6 \%$ organic carbon by weight (Table 2 ). These relatively high percentages contrast with those of the green, red, and gray claystones, which are quite low (Fig. 3). Atomic C/ $\mathrm{N}$ ratios of the black claystones average 33 , whereas the values of interbedded organic-carbon-lean strata average about 12 (Table 2). Similar contrasts in organic-carbon contents and $\mathrm{C} / \mathrm{N}$ ratios have been observed in $\mathrm{Ce}$ nomanian black shales and adjacent green claystones (Meyers, Trull, et al., 1984) and have been interpreted as resulting from enhanced (but only partial) preservation of organic matter by rapid burial (the black shales) in a normally oxic depositional environment (the green claystones).

Highest organic-carbon values are concentrated in Cenomanian claystones. These values, averaging $3.8 \%$ and reaching $13.6 \%$ (Table 2 ), are significantly higher than most previously reported values from similar strata in the North American Basin (cf. Erdman and Schorno, 1978; Deroo et al., 1980; Summerhayes and Masran, 1984) which have $10.4 \%$ as a maximum.

Unit V consists of limestones and interbedded claystones, siltstones, and sandstones of Barremian to Berriasian age. Organic-carbon concentrations vary be- 
Table 1. Means and ranges of concentrations of calcium carbonate and organic carbon and atomic carbon nitrogen ratios in organic matter from lithologic units of Site 603 on the Outer Hatteras Rise.

\begin{tabular}{|c|c|c|c|c|c|c|c|c|c|c|}
\hline \multirow[b]{2}{*}{ Subunit } & \multirow[b]{2}{*}{ Lithology } & \multirow{2}{*}{$\begin{array}{l}\text { Sub-bottom } \\
\text { depth (m) }\end{array}$} & \multirow[b]{2}{*}{ Age } & \multirow{2}{*}{$\begin{array}{l}\text { Number } \\
\text { of } \\
\text { samples }\end{array}$} & \multicolumn{2}{|c|}{$\mathrm{CaCO}_{3} \%$} & \multicolumn{2}{|c|}{$\mathrm{C}_{\mathrm{org}} \%$} & \multicolumn{2}{|c|}{ Atomic $\mathrm{C} / \mathrm{N}$} \\
\hline & & & & & Mean & Range & Mean & Range & Mean & Range \\
\hline IA & $\begin{array}{l}\text { Nannofossil-bearing } \\
\text { clay/claystone }\end{array}$ & $0-448$ & $\begin{array}{l}\text { Pleistocene to } \\
\text { carly Pliocene }\end{array}$ & 137 & 10 & $1-35$ & 0.32 & $0.08-0.68$ & 9 & $6-13$ \\
\hline IB & $\begin{array}{l}\text { Quartz-mica-bearing } \\
\text { claystone }\end{array}$ & $448-698$ & $\begin{array}{l}\text { early Pliocene } \\
\text { to middle } \\
\text { Miocene }\end{array}$ & 36 & 2 & $1-6$ & 0.28 & $0.08-0.47$ & 7 & $5-10$ \\
\hline IC & $\begin{array}{l}\text { Biogenic-silica- } \\
\text { bearing claystone } \\
\text { and silt-rich } \\
\text { claystone }\end{array}$ & $698-950$ & middle Miocene & 29 & 6 & $0-10$ & 0.34 & $0.01-0.67$ & 9 & $3-12$ \\
\hline ID & Silt-rich claystone & $950-960$ & $\begin{array}{l}\text { middle Miocene } \\
\text { to Eocene }\end{array}$ & 5 & 2 & $1-6$ & 0.01 & 0.01 & 2 & $1-2$ \\
\hline II & $\begin{array}{l}\text { Radiolarian-bearing } \\
\text { claystone }\end{array}$ & $960-1023$ & Eocene & 11 & 1 & 1 & 0.01 & 0.01 & 4 & $2-5$ \\
\hline IIIA & Variegated claystones & $1023-1039$ & $\begin{array}{c}\text { Maestrichtian to } \\
\text { Santonian }\end{array}$ & 4 & 1 & 1 & 0.01 & 0.01 & 3 & $2-6$ \\
\hline IIIB & Variegated claystones & $1039-1084$ & Santonian & 8 & 3 & $1-8$ & 0.43 & $0.01-1.95$ & 10 & $3-36$ \\
\hline IIIC & $\begin{array}{l}\text { Variegated claystones } \\
\text { with black shales }\end{array}$ & $1084-1119$ & $\begin{array}{l}\text { Coniacian to } \\
\text { late Turonian }\end{array}$ & 5 & 2 & $1-4$ & 0.01 & 0.01 & 3 & $3-4$ \\
\hline IVA & $\begin{array}{l}\text { Black shales and } \\
\text { green claystones }\end{array}$ & $1119-1166$ & $\begin{array}{l}\text { Turonian to } \\
\text { Cenomanian }\end{array}$ & 23 & 1 & $1-7$ & 3.42 & $0.01-13.59$ & 30 & $10-44$ \\
\hline IVB & $\begin{array}{l}\text { Green and red } \\
\text { claystones with } \\
\text { black shales }\end{array}$ & $1166-1196$ & Albian & 9 & 1 & $1-2$ & 0.19 & $0.01-1.37$ & 13 & $4-38$ \\
\hline IVC & $\begin{array}{l}\text { Green claystones } \\
\text { with black shales }\end{array}$ & $1196-1205$ & Albian & 3 & 1 & $1-2$ & 1.01 & $0.01-2.74$ & 26 & $18-35$ \\
\hline IVD & $\begin{array}{l}\text { Green and red } \\
\text { claystones with } \\
\text { black shales }\end{array}$ & $1205-1215$ & Aptian to Albian & 2 & 1 & 1 & 0.01 & 0.01 & 6 & $5-7$ \\
\hline VA & $\begin{array}{l}\text { Maristone, sandstone, } \\
\text { and claystone } \\
\text { turbidites }\end{array}$ & $1215-1512$ & $\begin{array}{l}\text { Barremian to } \\
\text { Valanginian }\end{array}$ & 136 & 42 & 2-91 & 0.85 & $0.01-2.57$ & 35 & $11-64$ \\
\hline VB & $\begin{array}{l}\text { Marlstone, sandstone, } \\
\text { and claystone }\end{array}$ & $1512-1576$ & $\begin{array}{c}\text { Valanginian to } \\
\text { Berriasian }\end{array}$ & 11 & 66 & $53-89$ & 0.44 & $0.01-1.41$ & 33 & $18-75$ \\
\hline
\end{tabular}

Table 2. Means and ranges of organic carbon concentrations and organic matter carbon/nitrogen ratios in different lithologies from Cretaceous units at Site 603 .

\begin{tabular}{|c|c|c|c|c|}
\hline \multirow[b]{2}{*}{ Lithology ${ }^{a}$} & \multicolumn{2}{|c|}{$\mathrm{C}_{\mathrm{org}} \%$} & \multicolumn{2}{|c|}{ Atomic $\mathrm{C} / \mathrm{N}$} \\
\hline & Mean & Range & Mean & Range \\
\hline \multicolumn{5}{|l|}{ Unit III-Plantagenet Formation } \\
\hline Red claystones (15) & 0.01 & & 4.4 & $2.4-13.6$ \\
\hline Black shale (2) & 1.65 & $1.34-1.95$ & 20.7 & $5.8-35.6$ \\
\hline \multicolumn{5}{|l|}{ Unit IV-Hatteras Formation } \\
\hline Red claystones (5) & 0.01 & & 8.4 & $4.3-18.3$ \\
\hline Green claystones (4) & 0.15 & $0.01-0.28$ & 16.3 & $7.3-24.0$ \\
\hline Black shales (22) & 3.76 & $0.74-13.59$ & 32.9 & $22.9-44.1$ \\
\hline \multicolumn{5}{|l|}{ Unit V-Blake-Bahama Formation } \\
\hline Cemented sandstones (5) & 0.03 & $0.01-0.05$ & 20.4 & $10.9-24.0$ \\
\hline Bioturbated limestones (26) & 0.22 & $0.01-2.01$ & 31.7 & $18.2-60.3$ \\
\hline Sandstones (40) & 0.60 & $0.01-2.14$ & 36.0 & $15.8-52.0$ \\
\hline Laminated Limestones (46) & 1.01 & $0.12-2.42$ & 36.9 & $23.9-75.1$ \\
\hline Dark marlstones (33) & 1.47 & $0.06-2.57$ & 35.0 & $27.7-40.9$ \\
\hline
\end{tabular}

${ }^{a}$ Number of samples in parentheses.

tween virtually nil to over $2.6 \%$ in samples from this depth range (Tables 1 and 2) and are not related to lithology. The mean organic-carbon concentration of samples from this unit is $0.8 \%$. C/N ratios are higher in these samples than in Unit IV samples, ranging between
10.9 and 75.1 , and they suggest much of the organic matter in the rocks in this group originated from land plants (cf. Múller, 1977). Coaly stringers and pyritized wood fragments were commonly found in strata below $1220 \mathrm{~m}$ (Site 603 report, this volume) and support the likelihood of continental inputs dominating the sources of the organic matter in these rocks.

Rock-Eval pyrolysis was used in an attempt to characterize the type of organic matter in samples selected at about 100 -m intervals throughout Site 603 . Because many of these sediments contain so little organic matter, their $\mathrm{S}_{2}$ and $\mathrm{S}_{3}$ values are too low to be useful for source identification. Temperatures of $S_{2}$ maxima are between 362 and $416^{\circ} \mathrm{C}$ (Table 3) and indicate the organic matter is immature, except for one anomalous middle Miocene sample having a value of $462^{\circ} \mathrm{C}$, which may contain detrital organic matter.

The Cenomanian black shale samples from the Hatteras Formation generally have high hydrogen indexes (Table 3), representative of Type II kerogen of marine origin. Although most previous studies have concluded that the majority of the organic matter contained with North Atlantic Cretaceous black shales is from continental sources, Summerhayes and Masran (1984) suggest that samples with higher organic-carbon concentrations contain proportionately more marine organic matter. Moreover, some Cenomanian sediments from Site 105 are unusually rich in marine organic matter (Sum- 


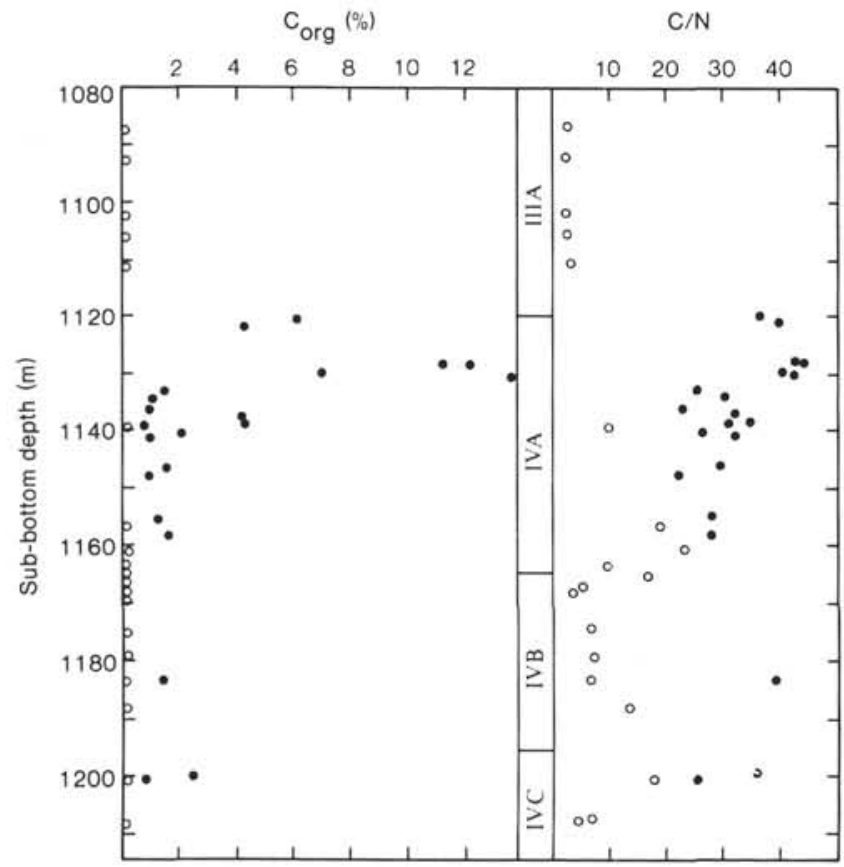

Figure 3. Concentrations of organic carbon and atomic carbon/nitrogen ratios in organic matter from samples from Subunits IIIC, IVA, IVB, and IVC (Plantagenet and Hatteras formations) of Hole 603B. Solid circles represent black shales, and open circles represent red and green claystones.

merhayes, in press) and Albian-Aptian sediments from Sites 417 and 481 are dominated by marine material (Deroo et al., 1980). The abundance of marine organic matter in Cenomanian sediments rich in organic carbon in
Hole 603B is therefore not unexpected and represents short episodes of enhanced preservation of marine material superimposed upon a low background of terrigenous organic matter. The rest of Unit IV, however, appears to be poor in marine organic matter.

Rock-Eval analysis of Unit V samples showed limestones to contain microbially reworked, detrital continental organic material, whereas some of the black, turbiditic marlstones have high hydrogen indexes (Table 3 ). The abrupt change from a predominantly terrigenous type to a more marine type of organic matter between Barremian and Aptian times, concurrent with the disappearance of limestones, is intriguing. It may indicate that transport of vast amounts of continental organic material to the North Atlantic stopped at the end of the Barremian age at the same time the CCD became shallower, or it may record enhanced accumulation of admixed marine organic matter in post-Barremian times.

Rock-Eval values of selected samples from the Hatteras and Blake-Bahama formations are plotted in Figure 4. All six "black shales" have high HI values, although the Neocomian Blake-Bahama marlstones have greater OI values than do the Cenomanian Hatteras claystones. Two limestones and a sandstone from the BlakeBahama Formation have similar, low Rock-Eval values characteristic of detrital organic matter. The contrast between the "black shales" and the other types of rocks suggests the major distinguishing feature in the organic matter content of the "black shales" is an enhanced marine component, although these western Atlantic samples by no means are as rich in marine organic matter as are black claystones from the eastern edge of this ocean (Summerhayes, in press).

Table 3. Rock-Eval data from Site 603 samples collected during DSDP Legs 93 and 95.

\begin{tabular}{|c|c|c|c|c|c|c|c|}
\hline $\begin{array}{c}\text { Sample } \\
\text { (interval in } \mathrm{cm} \text { ) }\end{array}$ & Lithology & $\begin{array}{l}\text { Sub-bottom } \\
\text { depth (m) }\end{array}$ & Age & $\mathrm{C}_{\text {org }} \%$ & HI & OI & $T_{\max }{ }^{\circ} \mathrm{C}$ \\
\hline $603-2-5,32-35$ & Nannofossil clay & 15.3 & late Pliocene & 0.56 & 0.3 & 23.4 & 393 \\
\hline $603-7-2,80-83$ & Nannofossil clay & 182.1 & Pliocene & 0.47 & 2.5 & 18.5 & 381 \\
\hline $603-15-2,78-81$ & Quartz-mica claystone & 326.1 & early Pliocene & 0.32 & 2.1 & 17.5 & 375 \\
\hline $603-22-5,80-81$ & Mica-bearing claystone & 474.6 & late Miocene & 0.35 & 1.2 & 14.6 & 374 \\
\hline $603-33-2,70-71$ & Quartz-mica claystone & 614.0 & middle Miocene & 0.13 & 17.8 & 21.5 & 462 \\
\hline $603-42-2,74-75$ & Mica-bearing claystone & 700.4 & middle Miocene & 0.26 & 0.8 & 13.1 & 383 \\
\hline $603-52-2,10-11$ & Opal-mica claystone & 795.8 & middle Miocene & 0.55 & 17.7 & 4.6 & 379 \\
\hline $603 \mathrm{~B}-7-1,72-74$ & Clay-rich, quartz siltstone & 850.0 & middle Miocene & 1.32 & 52.5 & 44.2 & 395 \\
\hline $603 \mathrm{~B}-26-4,28-29$ & Silt-rich claystone & 1061.4 & Santonian & 1.95 & 21.2 & 19.4 & 385 \\
\hline $603 \mathrm{~B}-33-3,10-11$ & Black shale & 1121.6 & Cenomanian & 4.14 & 314 & 24.3 & 383 \\
\hline $603 \mathrm{~B}-34-1,51-53$ & Black shale & 1128.0 & Cenomanian & 10.54 & 344 & 22.0 & 383 \\
\hline 603B-34-1, 72-74 & Black shale & 1128.2 & Cenomanian & 11.59 & 366 & 19.8 & 383 \\
\hline $603 \mathrm{~B}-34-2,135-137$ & Black shale & 1130.4 & Cenomanian & 13.59 & 271 & 21.4 & 378 \\
\hline 603 B- $34-4,76-78$ & Black shale & 1132.8 & Cenomanian & 1.35 & 40.3 & 15.5 & 399 \\
\hline $603 \mathrm{~B}-35-1,25-26$ & Black shale & 1136.8 & Cenomanian & 0.92 & 14.9 & 37.9 & 395 \\
\hline $603 \mathrm{~F}-4-1,26-28$ & Brown marlstone & 1201.1 & Albian & 1.93 & 124 & n.d. & 406 \\
\hline $603 F-4-6,15-17$ & Black marlstone & 1208.4 & Aptian & 2.49 & 84.3 & n.d. & 408 \\
\hline $603 \mathrm{~F}-4-6,70-72$ & Black marlstone & 1209.2 & Aptian & 1.90 & 226 & n.d. & 402 \\
\hline $603 \mathrm{E}-2-1,97$ & Black marlstone & 1259.9 & Barremian & 3.42 & 295 & n.d. & 401 \\
\hline 603 B-49-2, 72-74 & Black marlstone & 1264.6 & Barremian & 1.42 & 472 & 191.8 & 416 \\
\hline $603 \mathrm{E}-3-2,12$ & Limestone & 1278.6 & Barremian & 0.68 & 191 & n.d. & 394 \\
\hline $603 \mathrm{E}-3-2,55$ & Marlstone & 1279.1 & Barremian & 1.89 & 90 & n.d. & 398 \\
\hline $603 \mathrm{~B}-52-2,79-81$ & Sandstone & 1293.5 & Barremian & 2.14 & 9.3 & 11.2 & 383 \\
\hline $603 \mathrm{~B}-56-2,95-97$ & Laminated limestone & 1332.1 & Barremian & 1.79 & 4.6 & 37.7 & 399 \\
\hline $603 \mathrm{~B}-57-2,68-70$ & Laminated limestone & 1341.4 & Barremian & 0.59 & 30.6 & 30.6 & 397 \\
\hline $603 F-5-1,77-79$ & Not available & 1374.0 & Barremian & 1.55 & n.d. & n.d. & 406 \\
\hline $603 \mathrm{~B}-61-5,89-90$ & Black marlstone & 1384.5 & Barremian & 1.72 & 298 & 50.4 & 406 \\
\hline $603 \mathrm{~F}-8-2,56-58$ & Laminated limestone & 1516.2 & Valanginian & 1.33 & 60.2 & n.d. & 401 \\
\hline $603 F-8-2,131-132$ & Coaly limestone & 1519.0 & Valanginian & 19.05 & 159 & n.d. & 389 \\
\hline
\end{tabular}

Note: $\mathrm{n} \cdot \mathrm{d} .=$ not determined. 


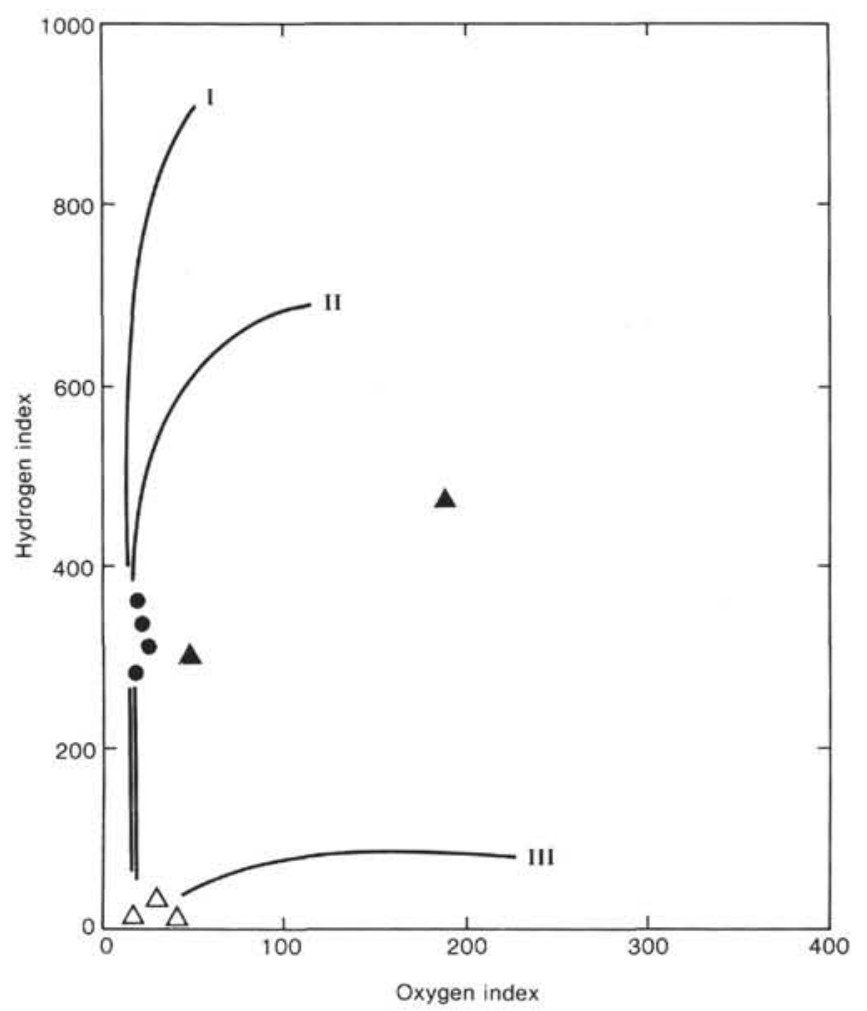

Figure 4. Rock-Eval plot of data from selected samples from Hole 603B. Solid circles represent Cenomanian Hatteras Formation black claystones. Solid triangles are from Neocomian Blake-Bahama Formation black marlstones. Open triangles are laminated limestones and a sandstone from the Blake-Bahama Formation.

\section{Sites 604 and 605-Upper New Jersey Rise}

Drilling of two holes at Site 604 (2328 m depth) and one at Site 605 (2194 m) (Fig. 1) provided a detailed record of sedimentation and sediment transport processes on the upper continental rise off New Jersey dating back to the late Maestrichtian. Figure 5 presents the lithologic units found at these sites. The site chapters (this volume) give details of these units.

Concentrations of organic carbon in sediments from Site 604 average $0.65 \%$ and vary between 0.06 and $2.11 \%$ (Table 4). Little relationship exists between these concentrations and sub-bottom depth except for Subunits IIC and IID between 179 and $239 \mathrm{~m}$ where relatively high values of 0.94 to $2.11 \%$ consistently appear. $\mathrm{C} / \mathrm{N}$ ratios range between 8 and 23 and, like organic-carbon concentrations, are not related to sediment depth. The $\mathrm{C} / \mathrm{N}$ values indicate that the organic matter in these sediments is a mixture of continental and marine material. The variability in concentrations of organic carbon and in $\mathrm{C} / \mathrm{N}$ ratios suggests that the proportions of terrigenous and aquatic materials have fluctuated somewhat over the period of time represented by this 250 -m-thick sequence of sediment.

The range of values of Site 605 samples is from 0.08 to 0.60 wt. $\%$ (Table 4 ), and the mean is $0.22-0.10 \%$, slightly below the mean of $0.3 \%$ calculated by McIver (1975) for DSDP Legs 1 through 31. Although organiccarbon concentrations are generally variable throughout
Site 605 sediments, those in Subunit IA are consistently greater than the mean value. A similar trend toward decreasing concentrations over the topmost sediment sections has been described for Leg 58 sediments from the western North Pacific (Waples and Sloan, 1980). Such downhole decreases are attributed to continued microbial degradation of organic matter after its burial in the seafloor.

Atomic $\mathrm{C} / \mathrm{N}$ ratios of the organic matter contents of Site 605 sediments average 25 for the 105 samples that had measurable nitrogen contents. This value is higher than those found in sediments of similar age at Sites 603 and 604 (Tables 1 and 4) and is characteristic of landplant organic material (Müller, 1977). C/N values, however, are quite variable at Site 605 , ranging between 5 to over 100 . This variability in $\mathrm{C} / \mathrm{N}$ ratios, when combined with the general variability of organic carbon concentrations, suggests fluctuations in the proportions of marine and continental contributions of organic matter to the sediments at this continental margin site.

\section{SUMMARY}

Organic-carbon concentrations are generally low in samples from Sites 603, 604, and 605 and reflect deposition of organic matter in well-oxygenated benthic settings and under areas of moderate to low productivity. At Site 603 a series of thin layers of Cenomanian black claystones exists in the Hatteras Formation surrounded by red and green claystones having very low amounts of organic carbon. The black strata are relatively rich in organic matter and have higher Rock-Eval HI values indicative of larger proportions of marine material. Similar organic-carbon-rich layers exists as black marlstones in the Neocomian Blake-Bahama Formation, but surrounded by limestones and sandstones containing detrital continental organic matter. The "black shale" layer appear to arise from turbiditic relocation of sediments from an ocean margin oxygen-minimum zone to the outer continental rise where reburial occurred under predominantly oxic bottom conditions. During Neocomian times, large amounts of continental organic matter also reached Site 603 by turbidity flow, but this material had already been oxidized at, or before reaching, its earlier marginal setting.

\section{ACKNOWLEDGMENTS}

Martha Tarafa kindly provided the Rock-Eval data from Holes 603E and $603 \mathrm{~F}$. I thank Brad Julson and Dennis Graham for so patiently carrying out the many shipboard analyses and Keith and Pam Dunham for their shore-based $\mathrm{CHN}$ measurements. I am especially grateful to the Deep Sea Drilling Project and the National Science Foundation for giving me the opportunity to participate on Leg 93 .

\section{REFERENCES}

Deroo, G., Herbin, J. P., Roucaché, J., and Tissot, B., 1980. Organic geochemistry of Cretaceous sediments at Deep Sea Drilling Project Holes 417D (Leg 51), 418A (Leg 52), and 418B (Leg 53) in the western North Atlantic. In Donnelly, T., Francheteau, J., Bryan, W., Robinson, P., Flower, M., Salisbury, M., et al., Init. Repts. $D S D P, 51,52,53$, Pt. 2: Washington (U.S. Govt. printing Office), 737-745.

Dunn, D. A., 1980. Revised techniques for quantitative calcium carbonate analysis using the "Karbonate Bombe," and comparisons 
to other quantitative carbon analysis methods J. Sediment. Petrol., 50:631-637.

Erdman, J. G., and Schorno, K. S., 1978. Geochemistry of carbon: Deep Sea Drilling Project Leg 44. In Benson, W. E., Sheridan, R. E., et al., Init. Repts. DSDP, 44: Washington (U.S. Govt. Printing Office), 605-615.

Espitalié, J., Madec, M., and Tissot, B., 1977. Source rock characterization method for petroleum exploration. Offshore Tech. Conf. Proc., pp. 399-404.

Ibach, L. E. J., 1982. Relationship between sedimentation rate and total organic carbon content in ancient marine sediments. Am. Assoc. Petrol. Geol. Bull., 66:170-188.

McIver, R., 1975. Hydrocarbon occurrences from JOIDES Deep Sea Drilling Project. Proc. Ninth World Pet. Congr., pp. 269-280.

Meyers, P. A., Brassell, S. C., and Huc, A. Y., 1984. Geochemistry of organic carbon in South Atlantic sediments from Deep Sea Drilling Project Leg 75. In Hay, W. W., Sibuet, J.-C., et al., Init. Repts. $D S D P, 75$ : Washington (U.S. Govt. Printing Office), 967-981.

Meyers, P. A., Trull, T. W., and Kawka, O. E., 1984. Organic geochemical comparison of Cretaceous green and black claystones from Hole 530A in the Angola Basin. In Hay, W. W., Sibuet, J.-C., et al., Init. Repts. DSDP, 75: Washington (U.S. Govt. Printing Office), $1009-1018$.

Müller, G., and Gastner, M., 1971. The "Karbonate-Bombe," a simple device for determination of the carbonate content in sedi-

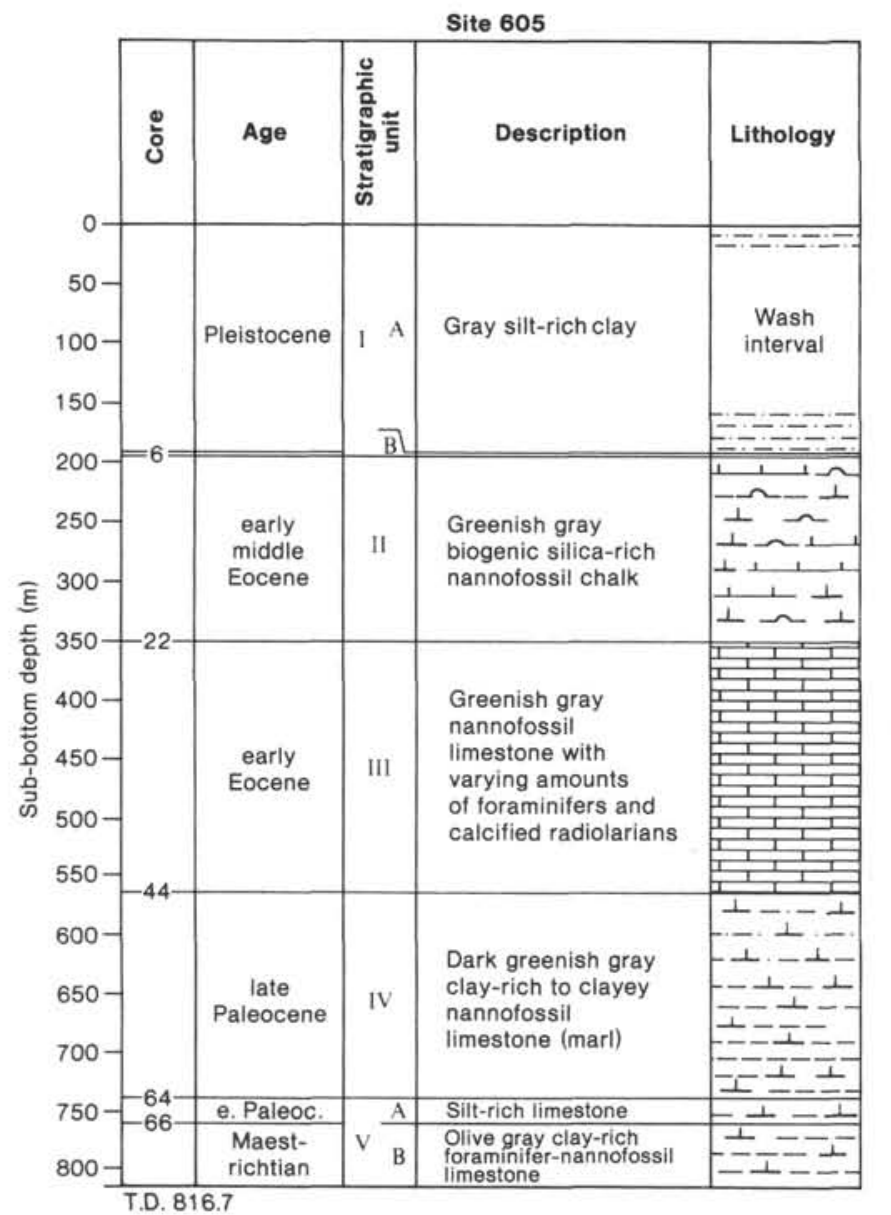

ments, soils and other materials. Neues Jahrb. Mineral. Monatch., $10: 466-469$

Müller, P. J., 1977. C/N ratios in Pacific deep-sea sediments: Effect of inorganic ammonium and organic nitrogen compounds absorbed by clays. Geochim. Cosmochim. Acta, 41:765-776.

Müller, P. J., and Suess, E., 1979. Productivity, sedimentation rate and sedimentary organic matter in the oceans-I. Organic carbon preservation. Deep-Sea Res., 26A:1347-1362.

Premuzic, E. T., Benkovitz, C. M., Gaffney, J. S., and Walsh, J. J., 1982. The nature and distribution of organic matter in the surface sediments of world oceans and seas. Org. Geochem., 4:63-77.

Summerhayes, C. P., in press. Organic rich Cretaceous sediments from the North Atlantic. In Brooks, J., and Fleet, A. J. (Eds.), Marine Petroleum Source Rocks: Oxford (Blackwells).

Summerhayes, C. P., and Masran, T. C., 1984. Organic facies of Cretaceous and Jurassic sediments from Deep Sea Drilling Project Site 534 in the Blake-Bahama Basin, western North Atlantic. In Sheridan, R. E., Gradstein, F. M., et al., Init. Repts. DSDP, 76: Washington (U.S. Govt. Printing Office), 469-480.

Waples, D. W., and Sloan, J. R., 1980. Carbon and nitrogen diagenesis in deep sea sediments. Geochim. Cosmochim. Acta, 44:14631470.

Date of Initial Receipt: 20 May 1985

Date of Acceptance: 13 December 1985
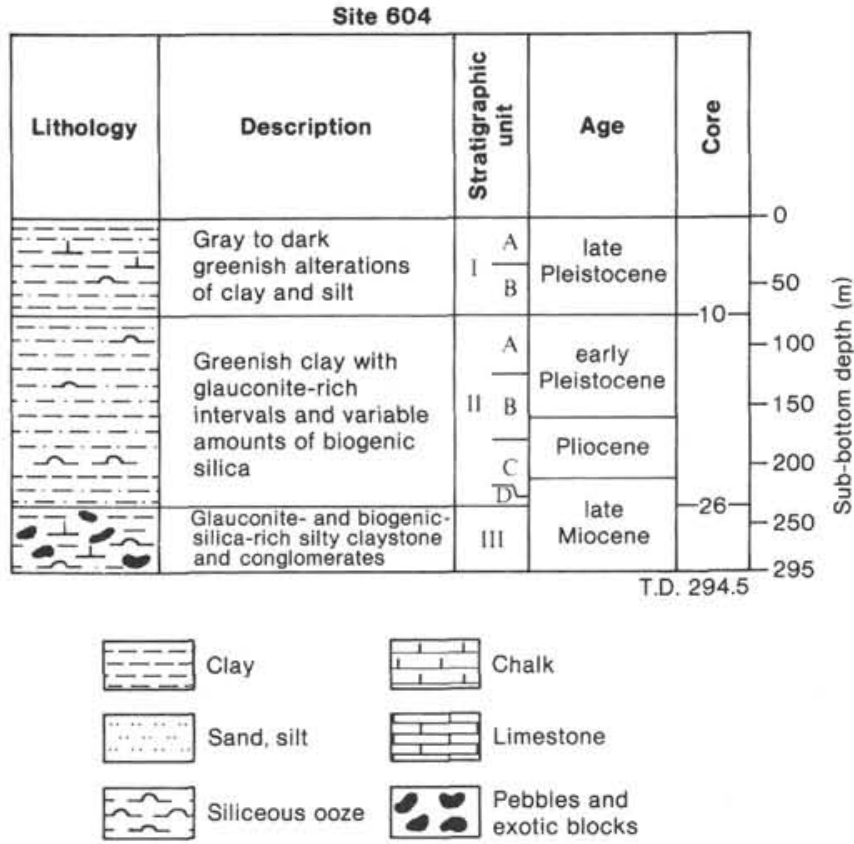

Figure 5. Stratigraphic summaries of Sites 604 and 605 on the New Jersey continental slope. 


\section{P. A. MEYERS}

Table 4. Means and ranges of concentrations of organic carbon and calcium carbonate and atomic carbon/nitrogen ratios in organic matter from lithologic units of Sites 604 and 605 on the New Jersey continental slope.

\begin{tabular}{|c|c|c|c|c|c|c|c|c|c|c|}
\hline \multirow[b]{2}{*}{ Subunit } & \multirow[b]{2}{*}{ Lithology } & \multirow{2}{*}{$\begin{array}{l}\text { Sub-bottom } \\
\text { depth }(\mathrm{m})\end{array}$} & \multirow[b]{2}{*}{ Age } & \multirow{2}{*}{$\begin{array}{c}\text { Number } \\
\text { of } \\
\text { samples }\end{array}$} & \multicolumn{2}{|c|}{$\mathrm{CaCO}_{3} \%$} & \multicolumn{2}{|c|}{$\mathrm{C}_{\text {org }} \%$} & \multicolumn{2}{|c|}{ Atomic $\mathrm{C} / \mathrm{N}$} \\
\hline & & & & & Mean & Range & Mean & Range & Mean & Range \\
\hline \multicolumn{11}{|l|}{ Site 604} \\
\hline IA & Clay and silt & $0-35$ & $\begin{array}{l}\text { Holocene to } \\
\text { Pleistocene }\end{array}$ & 4 & 10 & $8-14$ & 0.45 & $0.19-1.09$ & 12 & $10-14$ \\
\hline IB & Clay and silt & $35-84$ & $\begin{array}{l}\text { Holocene to } \\
\text { Pleistocene }\end{array}$ & 4 & 7 & $5-10$ & 0.31 & $0.06-0.79$ & 15 & $13-16$ \\
\hline IIA & Greenish gray clay & $84-122$ & $\begin{array}{l}\text { early Pleistocene } \\
\text { to late Miocene }\end{array}$ & 5 & 7 & 4-9 & 0.35 & $0.17-0.83$ & 16 & $14-18$ \\
\hline IIB & Clay with sand & $122-179$ & $\begin{array}{l}\text { early Pleistocene } \\
\text { to late Miocene }\end{array}$ & 12 & 10 & $2-19$ & 0.62 & $0.07-1.06$ & 13 & $8-23$ \\
\hline IIC & Clay with biogenic silica & $179-227$ & $\begin{array}{l}\text { early Pleistocene } \\
\text { to late Miocene }\end{array}$ & 5 & 9 & $7-12$ & 1.03 & $1.00-1.10$ & 13 & $12-13$ \\
\hline IID & Clay with sand and silica & $227-239$ & $\begin{array}{l}\text { early Pleistocene } \\
\text { to late Miocene }\end{array}$ & 3 & 3 & $2-5$ & 1.37 & $0.94-2.11$ & 16 & $14-19$ \\
\hline III & $\begin{array}{c}\text { Silty claystone and } \\
\text { conglomerates }\end{array}$ & $239-294$ & late Miocene & 1 & 59 & - & 0.22 & - & 3 & - \\
\hline \multicolumn{11}{|l|}{ Site 605} \\
\hline IA & Gray silty clay & $0-198$ & Pleistocene & 7 & 11 & $8-18$ & 0.36 & $0.32-0.42$ & 27 & $20-33$ \\
\hline IB & Green calcareous clay & $198-198.1$ & Pleistocene & 0 & - & - & - & - & - & - \\
\hline II & Siliceous nannofossil chalk & $198-350$ & middle Eocene & 12 & 53 & $44-61$ & 0.13 & $0.09-0.19$ & 23 & $5-36$ \\
\hline III & Nannofossil limestone & $350-564$ & early Eocene & 42 & 39 & $23-66$ & 0.20 & $0.08-0.60$ & 23 & $6->100$ \\
\hline IV & Nannofossil marlstone & $564-740$ & late Paleocene & 34 & 34 & $9-56$ & 0.27 & $0.15-0.52$ & 33 & $8->100$ \\
\hline VA & Nannofossil limestone & $740-760$ & early Paleocene & 3 & 26 & $12-47$ & 0.16 & $0.15-0.17$ & 17 & $16-18$ \\
\hline VB & $\begin{array}{l}\text { Foraminifer-nannofossil } \\
\text { limestone }\end{array}$ & $760-817$ & Maestrichtian & 10 & 58 & $41-68$ & 0.17 & $0.13-0.23$ & 14 & $6-33$ \\
\hline
\end{tabular}

